\title{
Toward reference intervals for shellfish: An illustrative case of feeding and respiratory activities in the Pacific cupped oyster, Crassostrea gigas
}

François Cyrille ${ }^{1,{ }^{*}}$, Haure Joel ${ }^{1,{ }^{*}}$, Billy Jean-Christophe ${ }^{2}$, Renault Tristan ${ }^{3}$

\author{
${ }^{1}$ RBE-SG2M-LGPMM IFREMER La Tremblade, France \\ 2 RBE-SG2M-PMMLT IFREMER La Tremblade, France \\ ${ }^{3}$ Département RBE Centre Atlantique IFREMER Nantes, France \\ *Corresponding authors : Cyrille François, email address : cyrille.francois@ifreme.fr : Joël Haure, email \\ address : joel.haure@ifremer.fr
}

\begin{abstract}
Background

The Quality Assurance and Laboratory Standards Committee of the American Society for Veterinary Clinical Pathology and the guidelines of the Clinical and Laboratory Standards Institute provide a framework for establishing reference intervals of physiological parameters in reputedly healthy individuals, humans, and terrestrial animals, respectively. This framework was applied for the first time to the Pacific cupped oyster, Crassostrea gigas. Reference intervals (RIs) would, first, be of interest for research purposes, including pathophysiology studies. RI determination is the first step before considering the use of RIs for field applications by farmers and marine shellfish health services.
\end{abstract}

\section{Objectives}

The purpose of this study was to propose reference intervals of feeding and respiration parameters, the clearance rate $(C R)$, and oxygen consumption rate $(\mathrm{OCR})$, in a reference population of hatchery-reared diploid Pacific oysters. Methods A de novo, a priori, and a direct approach were applied. The reference values acquired from 214 healthy diploid $C$ gigas (total wet weight 6.23-83.64 g, DW 0.06-1.87 g) were analyzed using a non-parametric statistical method.

Results

Reference intervals were proposed for $\mathrm{CR}, 0.7-4.1 \mathrm{~L} / \mathrm{h} / \mathrm{g}$ dry flesh weight (DW), and OCR, 0.4-1.3 mg $\mathrm{O} 2 / \mathrm{h} / \mathrm{g}$ DW in C gigas in a seawater at a temperature of $22^{\circ} \mathrm{C}$ and a salinity of $32 \%$. Animals were fed $30-$ 40 cells $/ \mu \mathrm{L}$ of Isochrysis affinis galbana. The confidence intervals at $90 \%$ of the upper limits of the two parameters were found to be higher than those of the Clinical and Laboratory Standards Institute (CLSI) recommendations. 


\section{Conclusions}

Obtaining reference intervals is an important step and must be completed by proposed decision limits to facilitate the early detection of health disorders in $\mathrm{C}$ gigas.

Keywords : Bivalvia, clearance rate, health, Ostreidae, oxygen consumption rate, reference values 


\section{$1 \quad$ Introduction}

Mass mortality events affecting bivalves including the Pacific cupped oyster Crassostrea gigas (Thunberg, 1793) have been related to infectious diseases in France and world-wide ${ }^{1}$. It appears of interest to develop physiopathology research activities to better understand the effects of diseases on the physiological functions of C. gigas. Among the parameters already used in ecophysiology, clearance and oxygen consumption rates are potential candidates for the first step of characterizing the physiologic behavior of healthy Pacific oysters. In healthy conditions, clearance and oxygen consumption were shown to vary according to body size and environmental conditions. Small oysters have a relatively higher physiological activity than large oysters ${ }^{2}$. Clearance rate and oxygen consumption follow a non-linear function relative to the dry flesh weight (DW) and allometry should be taken into account in order to standardize the results of physiological functions studied ${ }^{3-4}$. Temperature ${ }^{5-7}$, salinity ${ }^{7}$ and the quantity or quality of suspended matter ${ }^{2,6,8}$ have shown to be the main environmental factors of influence on C. gigas metabolism. Some authors showed that clearance and oxygen consumption rates also fluctuate during infections with pathogens in oysters ${ }^{9-12}$. They could be measured simultaneously, at high flow rate with a non-invasive approach allowing the preservation of the animal's integrity ${ }^{13}$. Thus, Barber et al. ${ }^{10}$ showed a negative energy balance in oysters infested with parasite Haplosporidium nelsoni resulting from a decrease in the clearance rate without modification of the oxygen consumption rate. Soletchnik et al. ${ }^{11}$ showed a positive linear relationship between gill abnormalities and filtration rate for starved and Skeletonema fed C. gigas. In populations known to be infected with Chlamydia-like organism, clearance rate estimates represent a better bioindicator for high infection level than compared to either physiological measurements (respiration, feces production) or estimates (absorption rate, scope for growth). They also showed a negative correlation between respiration and gill abnormalities induced by Chlamydia-like in C. gigas and related it to gill malfunction. Richard et al. ${ }^{12}$ noted that injection of OsHV-1 (Oyster Herpesvirus type 1) induces a decrease in oxygen consumption in juvenile C. gigas. Another study also showed a disruption of both rates in C. gigas following heat stress ${ }^{14}$. The Quality Assurance and Laboratory Standards Committee of the American Society for Veterinary Clinical Pathology (ASVCP-QALS) and the guidelines of the Clinical and Laboratory Standards Institute (CLSI) were initially devoted to proposing recommendations for establishing reliable reference intervals for use in clinical laboratory medicine ${ }^{15-17}$. This methodology will also benefit research studies in the field of physiology, by giving a rigorous framework and introducing the concept of reference intervals. 
74 The present study proposes to apply this framework in a de novo, a priori and direct approach to establish

75 reference intervals of clearance and oxygen consumption rates in a reference sample group of C. gigas $(\mathrm{n}=214$,

76 total wet weight $6.23-83.64 \mathrm{~g}$, dry flesh weight $0.06-1.87 \mathrm{~g}$ ) under reproducible laboratory conditions (seawater

77 at $22{ }^{\circ} \mathrm{C}$ and $32 \%$ salinity, phytoplankton resources $30-40$ cells/ $\mu 1$ Isochrysis affinis galbana (clone T-Iso)). 


\section{Material and methods}

\subsection{Clearance feeding and respiration functions as variables of interest}

Like most bivalves, C. gigas has gills that contribute to its nutritional and breathing needs. Nutritional function is approximated by clearance rate, which represents the volume of water filtered at $100 \%$ per hour and per gram of dry flesh weight $(1 / \mathrm{h} / \mathrm{gDW})$. Respiration function is defined by oxygen consumption rate in 1 hour and per gram of dry flesh weight (mgO2/h/gDW).

In order to take into account the physiological variability induced by various environmental factors and also to obtain an optimal response of filtration and oxygen consumption, the reference intervals were determined:

i) at $22{ }^{\circ} \mathrm{C}$, which seems to be a good compromise of temperature to measure the two physiological functions. According to the models of Bougrier et al. ${ }^{5}$, between 18 and $24{ }^{\circ} \mathrm{C}$, the clearance rate of C. gigas would be maximal, respectively 4.8 and $4.5 \mathrm{l} / \mathrm{h} / \mathrm{gDW}$ and the expected oxygen consumption rate would be 0.9 to $1.2 \mathrm{mgO} 2 / \mathrm{h} / \mathrm{gDW}$;

ii) outside the gametogenesis period to avoid difficulties in explaining the oxygen consumption rate variations during gametogenesis as described by Soletchnik et al. ${ }^{18}$ in C. gigas;

iii) with food of constant quality and quantity, to avoid an increase in clearance rate at low suspended particulate matter ${ }^{19}$ or a decrease in retention efficiency at high suspended particulate matter ${ }^{20}$ in C. gigas;

iv) with constant salinity (32\%o). Indeed, several studies have shown variations of clearance rate ${ }^{21-22}$ and oxygen consumption rate ${ }^{3,22}$ depending on salinity in Crassostrea virginica.

\subsection{Reference population}

The reference population used in this study consisted of supposedly healthy diploid C. gigas produced in IFREMER's experimental facilities. Young oysters (F1) were produced in August 2015 by cross-breeding 94 spawners (70 females and 24 males) and maintained in a secure and controlled environment until January 2017 for the study of reference intervals determination. 
109 The selection criteria of the reference sample group are established a priori in view to ensuring that only healthy

110 individuals are selected for the study (Table 1). A questionnaire was used to evaluate the conformity of 111 individuals to the selection criteria. Documents such as animal registry and the physical inspection of individuals 112 were considered systematically, to ensure that no disease occurred. After the acquisition of the reference values, 113 the lyophilized flesh of each animal was stored for diagnostic tests in the case of mortality event and/or suspicion 114 of infectious disease.

115 The number of reference individuals collected (>120) was chosen to estimate the confidence interval of $90 \%$ for 116 the reference limits using non-parametric statistical analysis. 214 individuals were selected directly from the reference population by applying the criteria (Table 1).

\subsection{Acclimation of reference individuals}

Reference individuals of the reference sample group were placed for an acclimation period of 8 days to reach a salinity of $32 \%$ and a temperature of $22{ }^{\circ} \mathrm{C}$ in tanks filled with seawater from natural source previously filtered at $30 \mu \mathrm{m}$ (sand filter), then $10 \mu \mathrm{m}$ (bag filter) and treated by ultraviolet sterilizer (low-pressure UV, $6 \mathrm{~m} / \mathrm{h}, 33$ $\mathrm{mJ} / \mathrm{cm}^{2}$ ) to prevent infectious pathogens. The phytoplankton Isochrysis affinis galbana (clone T-Iso) was supplied continuously to maintain the concentration of food at between 30 and 40 cells $/ \mu$ l.

\subsection{Reference values acquisition}

Reference values of clearance and oxygen consumption rates were obtained using the apparatus for physiology trials presented in Figure 1. Treated seawater (sand filter and UV sterilizer) and phytoplankton Isochrysis affinis galbana (clone T-Iso) were mixed in a tank (1), then distributed by a pump (2) into fifteen chambers (3), each containing a single oyster, plus a control chamber (4) without oyster. The phytoplankton Isochrysis affinis galbana (clone T-Iso) was supplied continuously to maintain the concentration of food at between 30 and 40 cells $/ \mu 1$. The flow rate for each chamber was set at $13 \mathrm{l} / \mathrm{h}$ so that the oysters would not use up more than $30 \%$ of phytoplankton resources ${ }^{23}$. An air diffuser was placed in the tank (1) in order to have more than $80 \%$ of air saturation. Each measurement chamber (volume 2 l) was equipped with an electromagnetic valve (two-way) (5) 
controlled by a computer (6). When the electromagnetic valve of one measuring chamber was opened, the water released was analyzed each second for 1 minute using an oximeter (Hach Lange Orbisphere 410 with M1100 LDO probe) (7) to determine oxygen consumption, then a fluorometer (Seapoint Chlorophyll-a Fluorometer SCF) (8) to estimate the clearance rate. The fluorometer and oximeter are checked before each trial. During this period the water in the other chambers was removed via a waste circuit (9). At the end of 1 minute, the cycle was complete and was then initiated in another chamber. The reference values calculations are performed on the averaged data of the last 5 seconds of the chamber being acquired, the first 55 seconds corresponding to the flushing of the residual seawater from the previous chamber in the pipe. Thus, the activity of an animal was measured every 16 minutes over a total time of 129 minutes ( 8 acquisitions of 5 seconds in 129 minutes). At the end of each trial, the oyster flesh is separated from the shell. The flesh is examined for any abnormality, placed in a sampling bag and frozen at $-20^{\circ} \mathrm{C}$ for 24 hours, then lyophilized for 48 hours and weighed to the nearest $0.01 \mathrm{~g}$.

The clearance rate was calculated as follows:

$$
\text { Clearance rate }(\mathrm{CR})(1 / \mathrm{h})=F \times[(\mathrm{I}-\mathrm{O}) / \mathrm{I}]
$$

where $\mathrm{F}$ is the flow rate $(1 / \mathrm{h})$ of each unit of measurement; I the fluorescence measured at the outlet of the control unit; $\mathrm{O}$ the fluorescence measured at the outlet at the experimental unit ${ }^{13}$.

The oxygen consumption was calculated as follows:

$$
\text { oxygen consumption rate }(\mathrm{OCR})(\mathrm{mg} / \mathrm{h})=\mathrm{F} \times(\mathrm{I}-\mathrm{O})
$$

where $\mathrm{F}$ is the flow rate $(1 / \mathrm{h})$ of each unit of measurement; $\mathrm{I}=$ concentration of oxygen $(\mathrm{mg} / \mathrm{l})$ at the outlet of the control unit; $\mathrm{O}$ the concentration of oxygen $(\mathrm{mg} / \mathrm{l})$ at the outlet at the experimental unit ${ }^{13}$.

Clearance and oxygen consumption rates were standardized using dry flesh weight (g). Small C. gigas filter and consume relatively more than larger oysters ${ }^{5}$. This observation may be explained by a smaller gill surface than other organs in larger animals ${ }^{24}$. In order to compare oysters of different size and weight, it is necessary to take into account the allometry according to the formula of Bayne et al. ${ }^{25}$ :

$$
\mathrm{Ys}=(\mathrm{Ws} / \mathrm{We})^{\mathrm{b}} \times \mathrm{Ye}
$$

where Ys is the physiological rate of activity of a standard animal, Ws is the dry flesh weight (1g as standard), We is the dry flesh weight of the experimental animal, Ye is the biological response of an experimental animal and $\mathrm{b}$ is the dry weight exponent or allometric coefficient of the physiological function calculated with the dataset of our study. 
169 Clearance and oxygen consumption rates data were stored in a Microsoft Excel®2010 file for further statistical

170 tests in freeware set of macroinstructions from Reference Value Advisor ${ }^{26}$ and Systat SigmaPlot ${ }^{\circledR}$ 3.2.

171 Reference Value Advisor was first used to propose the limits of the reference intervals with a corresponding $90 \%$

172 confidence interval and generate distribution histograms. The $90 \%$ CI were obtained using a non-parametric

173 bootstrap method after verifying the symmetric distribution of transformed data by the Box-Cox technique ${ }^{26}$.

174 The sample size was large enough to allow the use of a non-parametric statistical method. In addition to 175 reference intervals, means, median, standard deviations were calculated for each variable and regression analyses 176 were performed with Systat SigmaPlot ${ }^{\circledR}$ 3.2. 


\section{Results}

179

180

181

182

183

184

185

186

187

\subsection{Characteristics of the reference sample group}

Within the reference population, 214 individuals were selected according to the previously defined inclusion and exclusion criteria (Table 1). The total wet weight ranged from 6.23 to $83.64 \mathrm{~g}$. The dry flesh weight ranged from 0.06 to $1.87 \mathrm{~g}$ and the median value was $0.27 \mathrm{~g}$ dry flesh weight (Figure 2 ). These results demonstrate a nonGaussian distribution of dry flesh weight in the reference sample group with high representativeness of low weight animals since the mean value was $0.45 \mathrm{~g}$ dry flesh weight.

\subsection{Reference values and reference Intervals}

The allometric functions of clearance and oxygen consumption rates were established for a temperature of $22{ }^{\circ} \mathrm{C}$, based on their non-linear relationship $(\mathrm{p}<0.05)$ with the dry weight of animals (Figure 3$)$. The individual values were standardized using the allometric coefficients of 0.26 for clearance rate and 0.48 for oxygen consumption rate in order to calculate the reference values. Thus, the standardized mean values were $2.08 \mathrm{l} / \mathrm{h} / \mathrm{gDW}$ for the clearance rate and $0.86 \mathrm{mgO} 2 / \mathrm{h} / \mathrm{gDW}$ for the oxygen consumption rate under these experimental conditions.

The results concerning reference intervals are summarized in Table 2 and the corresponding histograms are shown in Figure 4. Both distributions were significantly different from the Gaussian (Anderson-Darling test, $\mathrm{p}<$ 0.05). No heterogeneity was detected by visual inspection of the histograms. Reference intervals were proposed in $C$. gigas for the first time: $0.7-4.1 \mathrm{l} / \mathrm{h} / \mathrm{gDW}$ for the clearance rate and $0.4-1.3 \mathrm{mgO} / \mathrm{h} / \mathrm{gDW}$ for the oxygen consumption rate. The widths of the $90 \% \mathrm{CI}$ of the upper limits of clearance and oxygen consumption rates in Figure 4 were wider than recommended by CLSI ${ }^{15}$. For the clearance rate, the width of the confidence intervals for the high limit was larger than 0.2 times the width of the reference interval $[(5.2-3.6)>(4.1-0.7) * 0.2]$. For the oxygen consumption rate, the width of the confidence interval for the high limit was larger than 0.2 times the width of the reference interval $[(1.5-1.3)>(1.3-0.4) * 0.2)]$. The widths of the $90 \%$ CI of the lower limits of clearance and oxygen consumption rates in Figure 4 were conform to CLSI ${ }^{15}$ document. 


\section{Discussion}

According to Siest et al. ${ }^{27}$, the acquisition of reference values based on a robust and reproducible approach began some forty years ago, but is still evolving today. The concept first focused on human physiology and then expanded to veterinary biology without yet addressing the world of invertebrates.

This study is the first to focus on the acquisition of reference values in marine bivalves, following the recommendations of CLSI ${ }^{15}$. The first step was to obtain an available population of healthy oysters with a known rearing story. This is why we choose to raise a population in hatchery, which is a secure structure compared to the natural environment.

215 The reference values were expressed according to the dry flesh weight and not according to the age of the animal

216 to allow comparison with published physiological data, but also because the weight of the animal's flesh has such

217 a pronounced effect on its metabolism that it is more consistent to present the results according to dry flesh 218 weight ${ }^{28}$.

219 Many authors have studied allometry to standardize physiological functions with the dry flesh weight of bivalves. In particular Shumway ${ }^{3}$ and Gosling ${ }^{4}$ summarized works on oxygen consumption and clearance rates and the allometry relations in several bivalves. In this work, it appears that the oyster C. gigas was not taken into account and we made the choice to compare our results with those of Bougrier et al. ${ }^{5}$ and Akashige et al. ${ }^{29}$ obtained at the temperatures closest to this study (Table 3):

i) The clearance and oxygen consumption rates calculated with the Bougrier et al. ${ }^{5}$ models at $22{ }^{\circ} \mathrm{C}$ (respectively 4.7 $\mathrm{l} / \mathrm{h} / \mathrm{gDW}$ and $1.1 \mathrm{mgO} 2 / \mathrm{h} / \mathrm{gDW}$ ) are included in the range of reference values obtained in this study. This is also the case for the oxygen consumption rate $(0.9 \mathrm{mgO} / \mathrm{h} / \mathrm{gDW})$ but not for the clearance rate $(8.8 \mathrm{l} / \mathrm{h} / \mathrm{gDW})$ calculated with the Akashige et al. ${ }^{29}$ models at $22^{\circ} \mathrm{C}$. The standardized mean values for the oxygen consumption rate obtained in this study are consistent with the literature. The standardized mean values for the clearance rate are on the other hand 2 times lower than those described by Bougrier et al. ${ }^{5}$ and 4 times lower than those described by Akashige et al. ${ }^{29}$. Several hypotheses are proposed to explain these differences. Algal cell concentrations were 7 times lower in Bougrier et al. ${ }^{5}$ and 50-60 times lower in Akashige et al. ${ }^{29}$ than

232 in our study. When the algal particles concentration is low, bivalves would increase their filtration effort to meet their energy requirement ${ }^{19,30}$ and lower the retention threshold to capture cells of smaller sizes ${ }^{20}$.

234 In addition, Bougrier et al. ${ }^{5}$ use a mixture of microalgae (Chaetoceros calcitrans, Isochrysis galbana) and 235 Akashige et al. ${ }^{29}$ use only C. calcitrans. The cells of C. calcitrans are 2 to 2.5 times larger than those of $I$. 
galbana (3 to $5 \mu \mathrm{m})^{31}$ and could be better captured, which could explain the differences in standardized mean values for clearance rate across studies.

ii) Table 2 shows that the allometric coefficients in this study are lower than those obtained by Bougrier et al. ${ }^{5}$ and Akashige et al. ${ }^{29}$. The choice of the reference sample can probably explain this result because this sample includes a high percentage of small animals $(<0.45 \mathrm{gDW})$ which shows low allometric coefficients relative for oxygen consumption and clearance rates.

Given the results obtained and at this stage of the discussion, it seems important to make some recommendations for the future determination of reference values in marine bivalves: i) be sure to work with a reference sample which has an identical number of individuals per dry flesh weight class, ii) to choose a microalgae similar in size to I. galbana and at a concentration between 30 and 40 cells $/ \mu$, iii) to use reproducible laboratory conditions (seawater at $22{ }^{\circ} \mathrm{C}$ and $32 \%$ salinity, similar experimental chamber and flow rate).

The clearance rate looks like a covariate of the oxygen consumption rate (Figure 5). At $22{ }^{\circ} \mathrm{C}$ there is a linear relation which reflects a relation in the activity of the two physiological functions in a reputedly healthy population. Above $22{ }^{\circ} \mathrm{C}$, it is likely that this relationship is no longer observed because the models of Bougrier et al. ${ }^{5}$ show a rapid decrease of clearance rate from $19{ }^{\circ} \mathrm{C}$ while oxygen consumption rate continues to increase with temperature up to $32{ }^{\circ} \mathrm{C}$.

The $90 \%$ confidence intervals at the upper limits of the two physiological functions were found to be high and not in accordance with CLSI recommendations. Conventional (non-parametric) statistical methods require a minimum of 120 values per analysis. In this study, 214 values were collected and, despite careful selection of the study population, the confidence intervals at the upper limits were larger than 0.2 times the width of the reference interval concerned ${ }^{15}$. As mentioned by Henny et al. ${ }^{32}$, the reference intervals may vary according to the sample of the population and the method of analysis. In addition, the change of species may justify noncompliance with the recommendations initially proposed for studies concerning human physiology. According to Ghiretti ${ }^{33}$, mollusks are probably the invertebrates with the greatest physiological variability within the same species due to intrinsic and extrinsic factors. Geffré ${ }^{34}$ also emphasized the difficulty of defining reference intervals in animal biology because of lack of knowledge of the breeding route, the fact that the animals are too easily stressed and because of insufficient numbers of animals. Here, the animals were chosen disease-free, maintained in a breeding environment kept the same from birth and studied under the same experimental conditions. This is why we suppose that the confidence intervals at the limit values are inherent to the physiological behavior of $C$. gigas and represent a result specific to the species studied. 
Today, oyster farmers obtain young oysters, called spat, from wild seed capture or from hatcheries. Their genetic characteristics can differ: spat from the wild are diploid while spat from hatcheries are either diploid or triploid, resulting from the crossing of breeders than can be selected for specific phenotypic traits. Triploids are assumed to be sterile and are produced in different ways, in particular by the cross-breeding of tetraploid males and diploid females in France ${ }^{35-37}$. Triploid oysters allocate little or no energy to reproduction, have a higher growth rate than diploid oysters and are marketed all year round without any gonad development, which can put consumers off. Given the interest of oyster farmers in the breeding of these animals, the outlook for further investigation points towards comparing the physiological activities of polyploid oysters to the RI determined in

274 this study.

275 The concept of reference values is widely used today in the medical field, provided that the reference group is 276 rigorously sampled ${ }^{38}$. Reference intervals are helpful to describe the biological characteristics of healthy animals; however they must not be confused with decision limits ${ }^{39}$ which are related to a clinical condition ${ }^{40}$

278 and allow assessing health status ${ }^{38}$.

279 This study is the first and essential step in approaching the health of marine bivalves, by taking the oyster as a 280 biological model and determining the reference intervals of its physiological functions; a further step would be to determine decision limits in view to carrying out an accurate diagnosis of the health status of $C$. gigas. Related developments are underway and others are being considered for future application, in particular during quarantine before introduction of oysters in a hatchery. 


\section{$5 \quad$ References}

1. Barbosa-Solomieu V, Renault T, Travers M-A. Mass mortality in bivalves and the intricate case of the Pacific oyster, Crassostrea gigas. J. Invertebr. Pathol. 2015; 131: 2-10. https://doi.org/10.1016/j.jip.2015.07.011.

2. Powell EN, Bochenek EA, Klinck JM, Hofmann EE. Influence of food quality and quantity on the growth and development of Crassostrea gigas larvae: a modeling approach. Aquaculture. 2002; 210(1): 89-117. https://doi.org/10.1016/S0044-8486(01)00891-2.

3. Shumway SE. Oxygen consumption in oysters: an overview. Mar. Biol. Lett. 1982; 3: 1-23.

4. Gosling E. Bivalve Molluscs. Gosling E: Blackwell Publishing Ltd; 2003; 4: 1-443.

5. Bougrier S, Geairon P, Deslous-Paoli JM, Bacher C, Jonquières G. Allometric relationships and effects of temperature on clearance and oxygen consumption rates of Crassostrea gigas (Thunberg). Aquaculture. 1995;

6. Dutertre M, Beninger PG, Barillé L, Papin M, Rosa P, Barillé A-L, Haure J. Temperature and seston quantity and quality effects on field reproduction of farmed oysters, Crassostrea gigas, in Bourgneuf Bay, France. Aquat. Living Resour. 2009; 22(3): 319-329. https://doi.org/10.1051/alr/2009042.

7. His E, Robert R, Dinet A. Combined effects of temperature and salinity on fed and starved larvae of the mediterranean mussel Mytilus galloprovincialis and the Japanese oyster Crassostrea gigas. Mar. Biol. 1989;

310 8. Barillé L, Prou J, Héral M, Razet D. Effects of high natural seston concentrations on the feeding, selection, 311 and absorption of the oyster Crassostrea gigas (Thunberg). J. Exp. Mar. Biol. Ecol. 1997; 212(2): 149-172. 312 https://doi.org/10.1016/S0022-0981(96)02756-6. 
314 9. Newell RIE. Physiological effects of the MSX parasite Haplosporidium nelsoni (Haskin, Stauber \& Mackin)

315 on the American oyster Crassostrea virginica (Gmelin). J. Shellfish Res. 1985; 5: 91-95.

316 https://www.biodiversitylibrary.org/item/18794\#page/103/mode/1up.

10. Barber BJ, Ford SE, Littlewood DTJ. A physiological comparison of resistant and susceptible oysters Crassostrea virginica (Gmelin) exposed to the endoparasite Haplosporidium nelsoni (Haskin, Stauber \& Mackin). J. Exp. Mar. Biol. Ecol. 1991; 146(1): 101-112. https://doi.org/10.1016/0022-0981(91)90256-V.

11. Soletchnik P, Goulletquer P, Cochennec N, Renault T, Geairon P. Ecophysiological study on the Pacific oyster Crassostrea gigas naturally infected by a Chlamydia-like microorganism: effect of infection level and diet on oyster physiological responses. Haliotis. 1998; 27: 1-19.

12. Richard M, Bourreau J, Montagnani C, Ouisse V, Gall P Le, Fortune M, Munaron D, Messiaen G, Callier MD, Roque E. Influence of OsHV-1 oyster mortality episode on dissolved inorganic fluxes: An ex situ experiment at the individual scale. Aquaculture. 2017; 475: 40-51. https://doi.org/10.1016/j.aquaculture.2017.03.026.

13. Haure J, Huvet A, Palvadeau H, Nourry M, Penisson C, Martin JLY, Boudry P. Feeding and respiratory time activities in the cupped oysters Crassostrea gigas, Crassostrea angulata and their hybrids. Aquaculture. 2003; 218(1): 539-551. https://doi.org/10.1016/S0044-8486(02)00493-3.

14. Buzin F. Optimisation des conditions hydrobiologiques pour la conservation de l'huître creuse Crassostrea gigas en système re-circulé (Optimization of hydrobiological parameters for the storage of the oyster Crassostrea gigas in recirculating systems). PhD Thesis, University of Nantes, France, 2011. Available at: http://archimer.ifremer.fr/doc/00092/20350/. Guidelines; document C28-A3. $3^{\text {rd }}$ ed. Wayne, PA: Clinical and Laboratory Standards Institute (CLSI); 2008. 
16. Friedrichs KR, Harr KE, Freeman KP, Szladovits B, Walton RM, Barnhart KF, Blanco-Chavez J. ASVCP reference interval guidelines: determination of de novo reference intervals in veterinary species and other related topics. Vet. Clin. Pathol. 2012; 41(4): 441-453. https://doi.org/10.1111/vcp.12006.

17. ASVCP Quality Assurance and Laboratory Standards Committee (QALS). Guidelines for the determination of reference intervals (RI) in veterinary species. Available at: https://www.asvcp.org/resource/resmgr/QALS/Other_Publications/RI_Guidelines_For_ASVCP_webs.pdf. Accessed April16, 2018.

18. Soletchnik P, Razet D, Geairon P, Faury N, Goulletquer P. Ecophysiology of maturation and spawning in oyster (Crassostrea gigas): Metabolic (respiration) and feeding (clearance and absorption rates) responses at different maturation stages. Aquat. Living Ressour. 1997; 10: 177-185. https://doi.org/10.1051/alr:1997019.

19. Dupuy C, Vaquer A, Lam - Höai T, Rougier C, Mazouni N, Lautier J, Collos Y, Le Gall S. Feeding rate of the oyster Crassostrea gigas in a natural phytoplankton community of the Mediterranean Thau Lagoon. Mar. Ecol. Prog. Ser, 2000; 205: 171-184. http://dx.doi.org/10.3354/meps205171.

20. Barillé L, Prou J, Héral M, Bougrier S. No influence of food quality, but ration-dependent retention efficiencies in the Japanese oyster Crassostrea gigas. J. Exp. Mar. Biol. Ecol. 1993; 171: 91-106. https://doi.org/10.1016/0022-0981(93)90142-B.

21. Mcfarland K, Donaghy L, Volety AK. Effect of acute salinity changes on hemolymph osmolality and clearance rate of the non-native mussel, Perna viridis, and the native oyster, Crassostrea virginica, in Southwest Florida. Aquat. Invasions, 2013; 8: 299-310. http://dx.doi.org/10.3391/ai.2013.8.3.06.

22. Casas SM, Lavaud R, La Peyre MK, Comeau LA, Filgueira R, La Peyre JF. Quantifying salinity and season effects on eastern oyster clearance and oxygen consumption rates. Mar. Biol, 2018; 165(90): 1-13. https://doi.org/10.1007/s00227-018-3351-x. 
23. Smaal AC, Widdows J. The scope for growth of bivalves as an integrated response parameter in biological

373 http://dx.doi.org/10.2331/suisan.71.762. 1994: 247-267. http://dx.doi.org/10.1016/0022-0981(87)90017-7. 0682. eng.pdf. monitoring. In: Kramer KJM, ed. Biomonitoring of coastal waters and estuaries. Boca Raton, FL: CRC Press;

24. Foster-Smith RL. The effect of concentration of suspension on the filtration rates and pseudofaecal production for Mytilus edulis (L.), Cerastoderma edule (L.) and Venerupis pullastra (Montagu). J. Exp. Mar. Biol. Ecol. 1975; 17: 1-22. https://doi.org/10.1016/0022-0981(75)90075-1.

25. Bayne BL, Hawkins AJS, Navarro E. Feeding and digestion by the mussel Mytilus edulis L. (Bivalvia: Mollusca) in mixtures of silt and algal cells at low concentrations. J. Exp. Mar. Biol. Ecol, 1987; 111: 1-22.

26. Geffré A, Concordet D, Braun J-P, Trumel C. Reference Value Advisor: a new freeware set of macroinstructions to calculate reference intervals with Microsoft Excel. Vet. Clin. Pathol. 2011; 40(1): $107-112$. https://doi.org/10.1111/j.1939-165X.2011.00287.x.

27. Siest G, Henny J, Gräsbeck R, Wilding P, Petitclerc C, Queralto JM, Petersen PH. The theory of reference values: an unfinished symphony. Clin. Chem. Lab. Med. 2013; 51(1): 47-64. https://doi.org/10.1515/cclm-2012-

28. Bernard FR. Physiology and Mariculture of some Northeastern Pacific Bivalve Molluscs. Can Spec Publ Fish. Aquat. Sci. 1984; 63: 1-24. http://publications.gc.ca/collections/collection_2016/mpo-dfo/Fs41-31-63-

29. Akashige S, Hirata Y, Takayama K, Soramoto K. Seasonal changes in oxygen consumption rates and filtration rates of the cultured Pacific oyster Crassostrea gigas. Nippon Suisan Gakk. 2005; 71(5): $762-767$. 

Evolution saisonnière de la filtration de bivalves intertidaux dans des conditions naturelles. Oceanis. 1987; 13(35): 575-579.

403

31. Robert R, His E. Growth and size frequency distribution of six marine unicellular algae in batch cultures used as food for larvae of bivalve molluscs. Rev. Trav. Inst. Pêches marit. 1985; 49(3-4): 165-173.

406

32. Henny J, Vassault A, Boursier G, Vukasovic I, Brguljan PM, Lohmander M, Ghita I, Bernabeu Andreu FA,

Kroupis C, Sprongl L, Thelen MHM, Vanstapel FJLA, Vodnik T, Huisman W, Vaubourdolle M. Recommendation for the review of biological reference intervals in medical laboratories. Clin. Chem. Lab. Med. 2016; 54(12): 1893-1900. https://doi.org/10.1515/cclm-2016-0793.

33. Ghiretti F. Respiration. In: Wilbur KM, Yonge CM, eds. Physiology of Mollusca. New York, NY: Academic Press; 1966; 2: 175-208.

34. Geffré A. Nouvelles approches de la production d'intervalles de référence de populations (New Approaches to producing population reference intervals). PhD Thesis, University of Toulouse, France, 2011. Available at: http://thesesups.ups-tlse.fr/1433/1/2011TOU30091.pdf.

35. Guo X, DeBrosse GA, Allen SK. All-triploid Pacific oysters (Crassostrea gigas Thunberg) produced by mating tetraploids and diploids. Aquaculture. 1996; 142(3): 149-161. https://doi.org/10.1016/00448486(95)01243-5.

36. Piferrer F, Beaumont A, Falguiere J-C, Flajshans M, Haffray P, Colombo L. Polyploid fish and shellfish: Production, biology and applications to aquaculture for performance improvement and genetic containment. Aquaculture. 2009; 293(3-4): 125-156. https://doi.org/10.1016/j.aquaculture.2009.04.036. 2015-0014. 
431 38. Petitclerc C. Normality the unreachable star? Clin. Chem. Lab. Med. 2004; 42(7): 698-701. 432 https://doi.org/10.1515/CCLM.2004.119.

433

434 39. Petersen PH, Jensen EA, Brandslund I. Analytical performance, reference values and decision limits. A need 435 to differentiate between reference intervals and decision limits and to define analytical quality specifications. 436 Clin. Chem. Lab. Med. 2012; 50(5): 819-831. https://doi.org/10.1515/cclm-2011-0844.

437

438 40. Ceriotti F. Quality specifications for the extra-analytical phase of laboratory testing: reference intervals and 439 decision limits. Clin. Biochem. 2017; 50(10-11): 595-598. https://doi.org/10.1016/j.clinbiochem.2017.03.024. 


\section{$441 \quad 6 \quad$ Acknowledgements}

442

443 This research action was funded in the framework of the EU project VIVALDI (H2020 program no.678589).

444 The authors wish to thank the hatchery team of the IFREMER station at La Tremblade, France. The authors

445 declare that there is no conflict of interest and the consent was obtained from all participants of the study. All

446 procedures performed in the study with animals met the ethical standards of the institution in accordance with

447 national and international guidelines.

448 
Table 1. Inclusion and exclusion criteria for the selection of reference individuals of Crassostrea gigas

\begin{tabular}{cc}
\hline Criteria & \\
\hline Biological & Species \\
& Genetic \\
& Physiology \\
\hline & Origin
\end{tabular}

Environment

Husbandry

Feeding

Medical history

Medical

Diagnostic

Medication

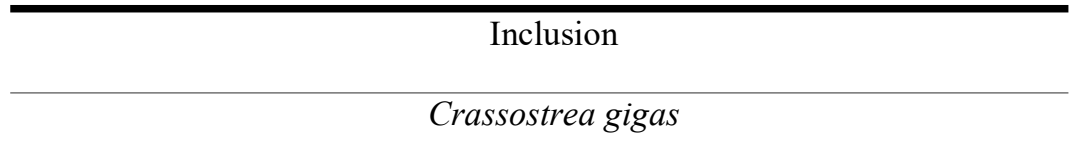

Spat to adult

Diploid, various gene pool

Hatchery with the same zootechnic history for all reference individuals

Seawater filtered to prevent known pathogen contamination,

with temperature and salinity controlled

Controlled food intake with one phytoplankton species identified

No illness in the two weeks preceding and during the study

Physical inspection: no signs of illness during the study

None

\begin{tabular}{c}
\hline Exclusion \\
\hline Others shellfish \\
Larvae \\
Polyploid, consanguinity \\
Stress \\
\hline Unknown zootechnic history
\end{tabular}

Environmental parameters not controlled

\section{Food intake not controlled (seston or}

various phytoplankton species not identified)

$$
\text { Lack of animal registry }
$$

Suspicion of disease

Preventive or curative care 
Table 2. Clearance and oxygen consumption rates reference intervals for healthy hatchery-reared Crassostrea gigas

453

\begin{tabular}{|c|c|c|c|c|c|c|c|c|c|c|c|}
\hline Variables & Units & $\mathrm{n}$ & Median & Mean & $\mathrm{SD}$ & Min & Max & $\begin{array}{l}\text { Centile } 2.5 \\
(90 \% \mathrm{CI})\end{array}$ & $\begin{array}{l}\text { Centile } 97.5 \\
(90 \% \mathrm{CI})\end{array}$ & Distribution & Method \\
\hline Clearance rate & 1/h/gDW & 214 & 1.9 & 2.1 & 0.8 & 0.5 & 5.5 & $0.7(0.6-1.0)$ & $4.1(3.6-5.2)^{*}$ & NG & NP \\
\hline $\mathrm{O} 2$ consumption rate & $\mathrm{mgO} 2 / \mathrm{h} / \mathrm{gDW}$ & 214 & 0.8 & 0.9 & 0.2 & 0.3 & 1.7 & $0.4(0.3-0.4)$ & $1.3(1.3-1.5)^{*}$ & $\mathrm{NG}$ & NP \\
\hline
\end{tabular}

454

$455 \mathrm{~N}$ indicates the number of reference individuals in the sample group; SD, standard deviation; Min, minimum; Max, maximum; CI, confidence interval; *, the $90 \%$ CI of one

456 (or more) limit is wider than recommended ${ }^{15}$; NG, non-Gaussian distribution; NP, non-parametric. 


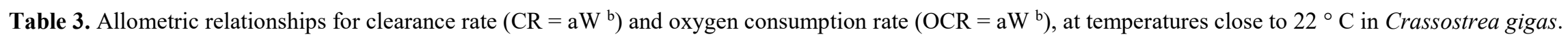

459

\begin{tabular}{|c|c|c|c|c|c|c|}
\hline Variables & Temperatures $\left({ }^{\circ} \mathrm{C}\right)$ & $\mathrm{n}$ & $\mathrm{a}$ & $\mathrm{b}$ & $\mathrm{R}^{2}$ & References \\
\hline \multirow[t]{10}{*}{ Clearance rate } & 20 & 28 & 4.28 & 0.33 & $0.26^{*}$ & Bougrier et al. ${ }^{5}$ \\
\hline & 20 & 32 & 4.86 & 0.70 & $0.54 *$ & Bougrier et al. ${ }^{5}$ \\
\hline & 20 & 12 & 3.37 & 0.71 & $0.35^{*}$ & Bougrier et al. ${ }^{5}$ \\
\hline & 23 & 13 & 4.51 & 0.42 & $0.35^{*}$ & Bougrier et al. ${ }^{5}$ \\
\hline & 19.3 & 14 & 4.78 & 1.04 & $0.87 * *$ & Akashige et al. ${ }^{29}$ \\
\hline & 20.4 & 21 & 6.20 & 0.56 & $0.56^{* *}$ & Akashige et al. ${ }^{29}$ \\
\hline & 21.5 & 16 & 5.01 & 0.91 & $0.64 * *$ & Akashige et al. ${ }^{29}$ \\
\hline & 21.5 & 30 & 11.20 & 0.61 & $0.52 * *$ & Akashige et al. ${ }^{29}$ \\
\hline & 23.9 & 21 & 10.24 & 0.72 & $0.86^{* *}$ & Akashige et al. ${ }^{29}$ \\
\hline & 22 & 214 & 2.08 & 0.26 & $0.21 *$ & This study \\
\hline \multirow[t]{8}{*}{ Oxygen consumption rate } & 20 & 27 & 0.86 & 0.95 & $0.81 *$ & Bougrier et al. ${ }^{5}$ \\
\hline & 20 & 35 & 0.85 & 0.61 & $0.66^{*}$ & Bougrier et al. ${ }^{5}$ \\
\hline & 20 & 22 & 1.08 & 0.81 & $0.76^{*}$ & Bougrier et al. ${ }^{5}$ \\
\hline & 23 & 23 & 1.12 & 0.58 & $0.68 *$ & Bougrier et al. ${ }^{5}$ \\
\hline & 18.6 & 25 & 0.62 & 0.73 & $0.90 * *$ & Akashige et al. ${ }^{29}$ \\
\hline & 21.5 & 27 & 0.89 & 0.84 & $0.73 * *$ & Akashige et al. ${ }^{29}$ \\
\hline & 22 & 30 & 1.02 & 0.62 & $0.48 * *$ & Akashige et al. ${ }^{29}$ \\
\hline & 22 & 214 & 0.86 & 0.48 & $0.57 *$ & This study \\
\hline
\end{tabular}

\section{0}

$461 \mathrm{~N}$ indicates the number of individuals in the sample group; $\mathrm{a}$, slope; $\mathrm{b}$, allometric coefficient; $\mathrm{R}^{2}$, determination coefficient; * significant ( $<0.05$ ) ANOVA, ** significant

$(\mathrm{p}<0.01)$ ANOVA. 
464 Figure 1. Experimental design for determining clearance and oxygen consumption rates in Crassostrea gigas

465 1: intake of treated seawater and phytoplankton; 2: pump for inlet adjustment; 3: measurement chamber; 4 :

466 control unit; 5: outlet valve control; 6: computer; 7: oxygen probe; 8: fluorometer; 9: waste circuit.

467

468 Figure 2. Frequency distribution of dry flesh weight of the 214 healthy hatchery-reared Crassostrea gigas of the 469 reference sample group

470 The blue vertical line (dash-dot- dot) represents the median and the red vertical line (short dash) the mean of dry 471 flesh weights.

472

473 Figure 3. Distribution of individual clearance (a) and oxygen consumption (b) rates for 214 healthy hatcheryreared Crassostrea gigas

475

Figure 4. Observed (blue boxes) and fitted (pink line) distributions of clearance (a) and oxygen consumption (b) rates for 214 healthy hatchery-reared Crassostrea gigas

479 The blue vertical lines are the limits of the reference interval with the corresponding $90 \%$ confidence intervals as dotted lines.

Figure 5. Clearance and oxygen consumption rates covariates in Crassostrea gigas

483 The solid line represents the linear regression line with the corresponding $95 \%$ confidence intervals as dotted lines; the short dashed lines represent the prediction limits. $n=214 ; p<0.001, R^{2}=040$. 


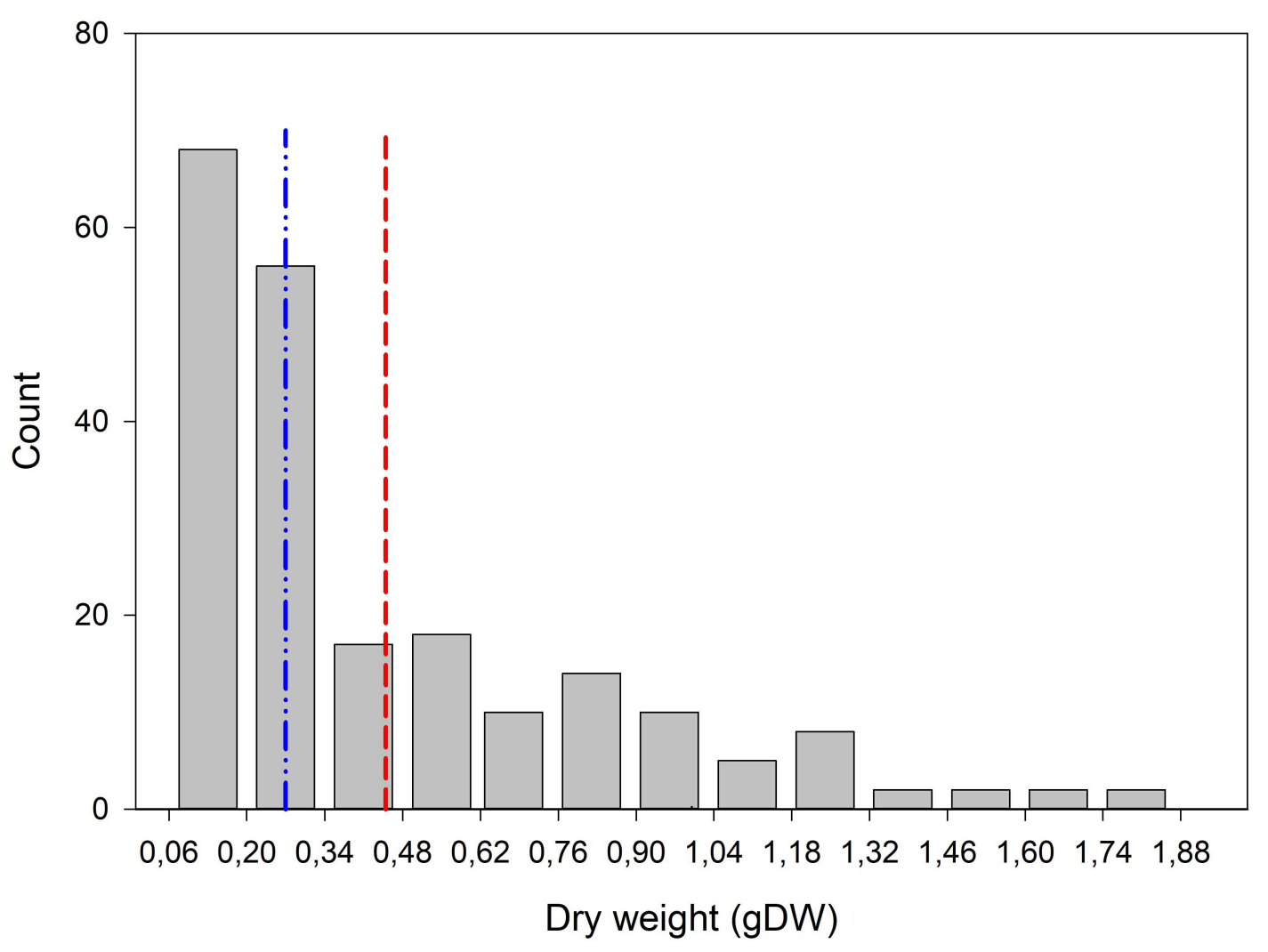




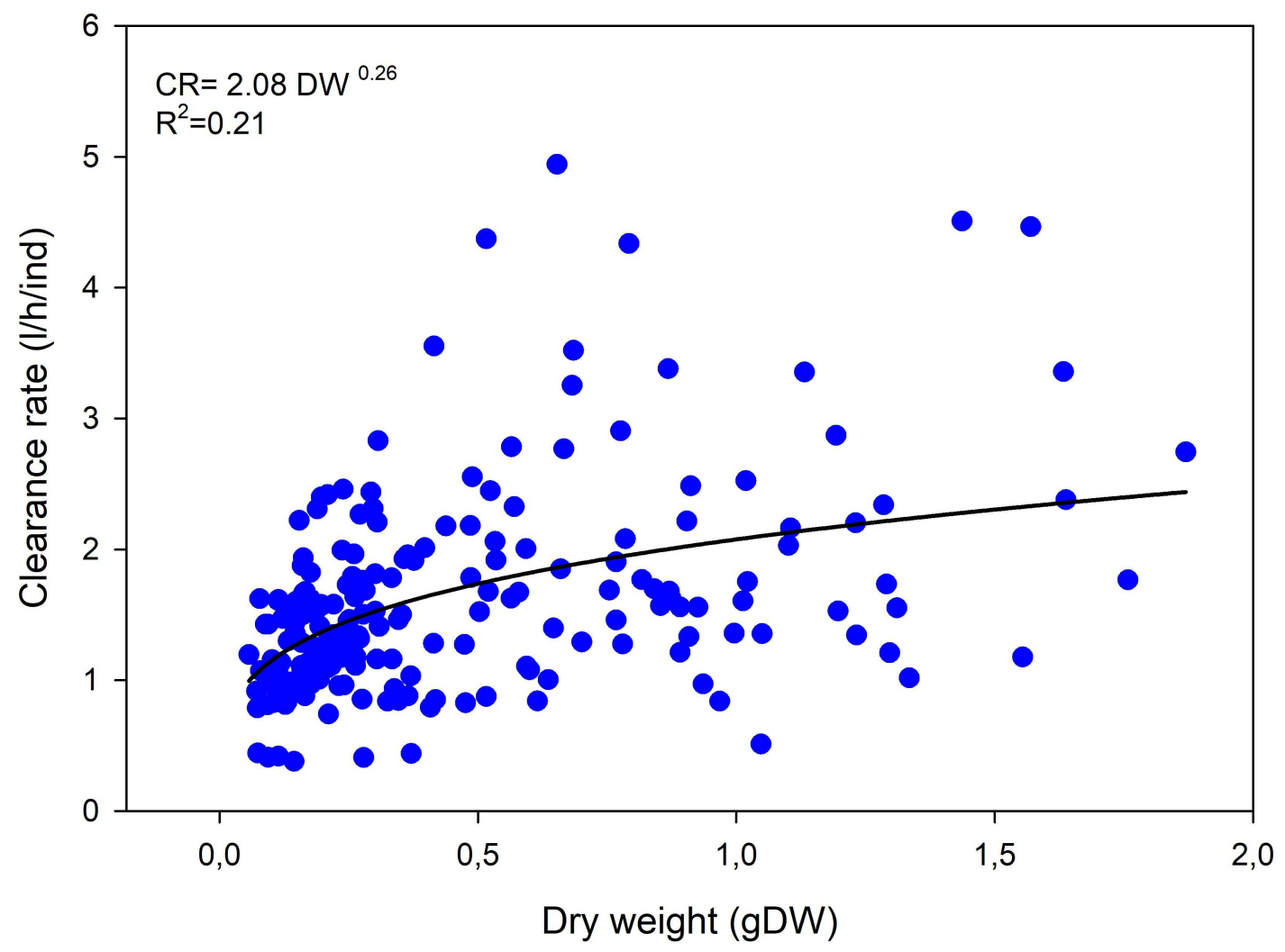




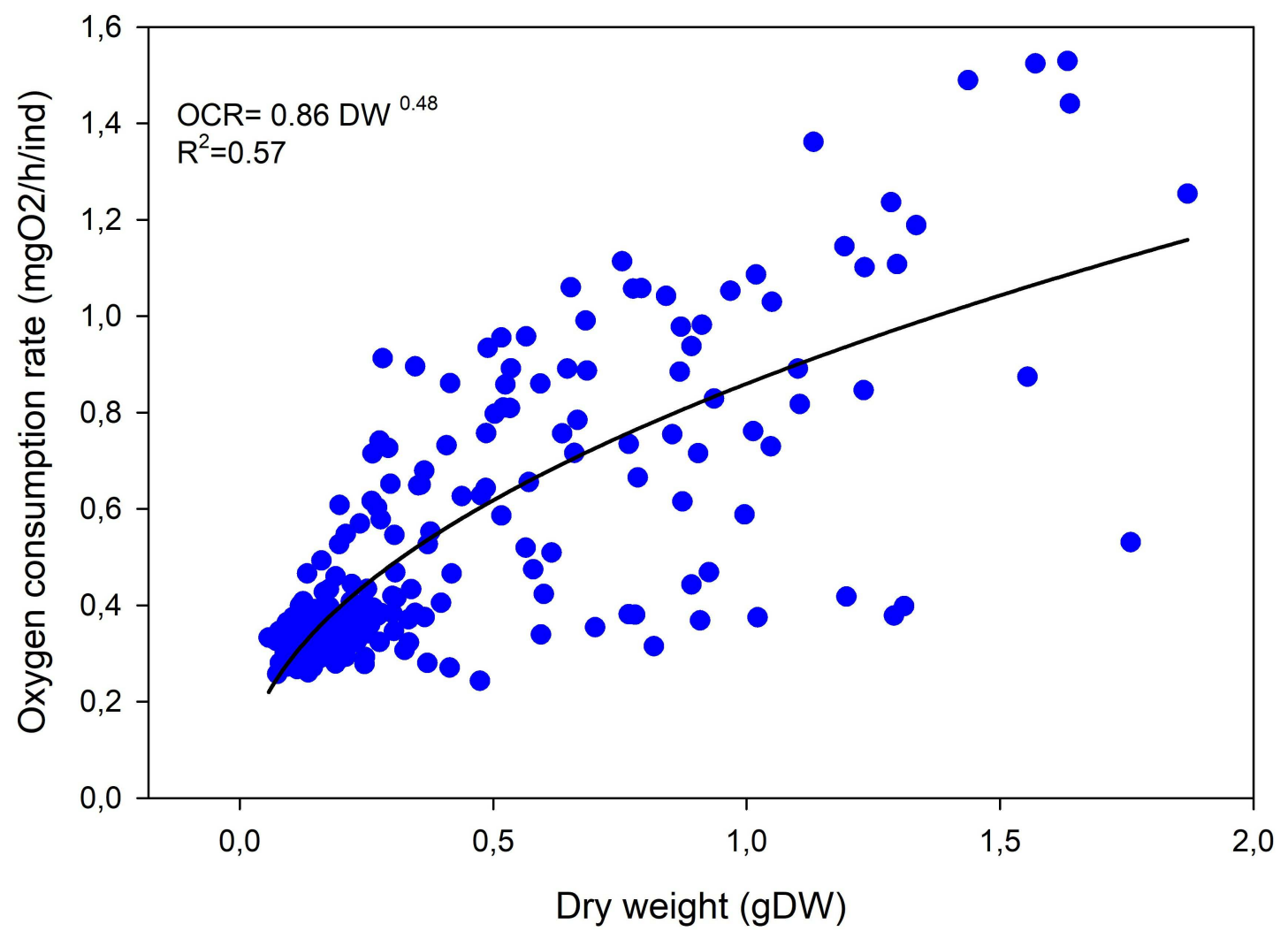




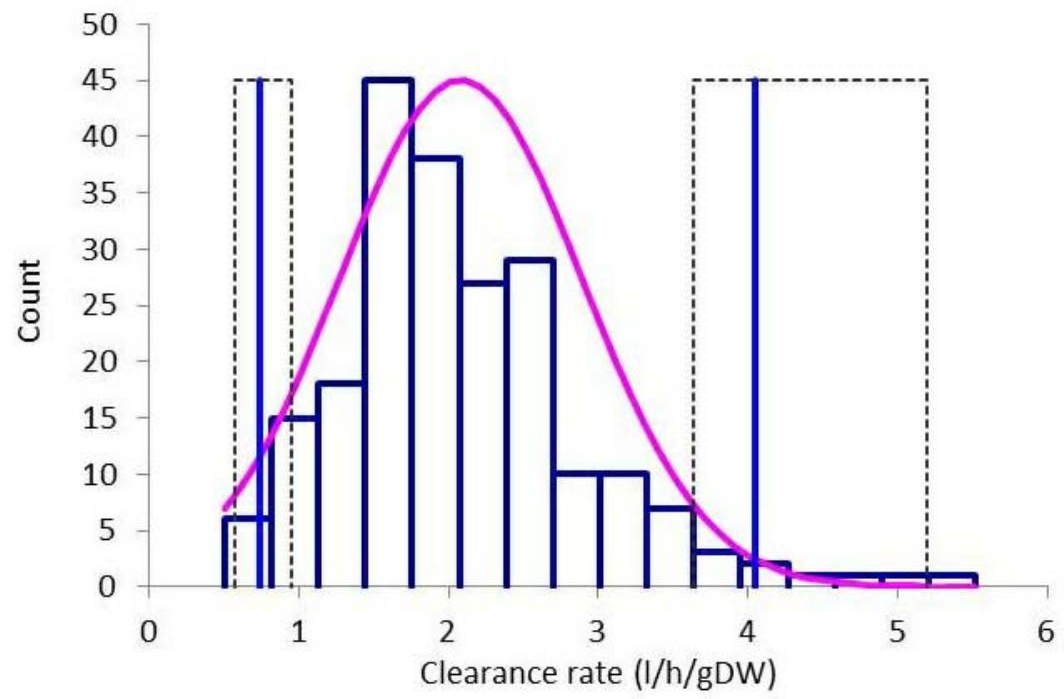




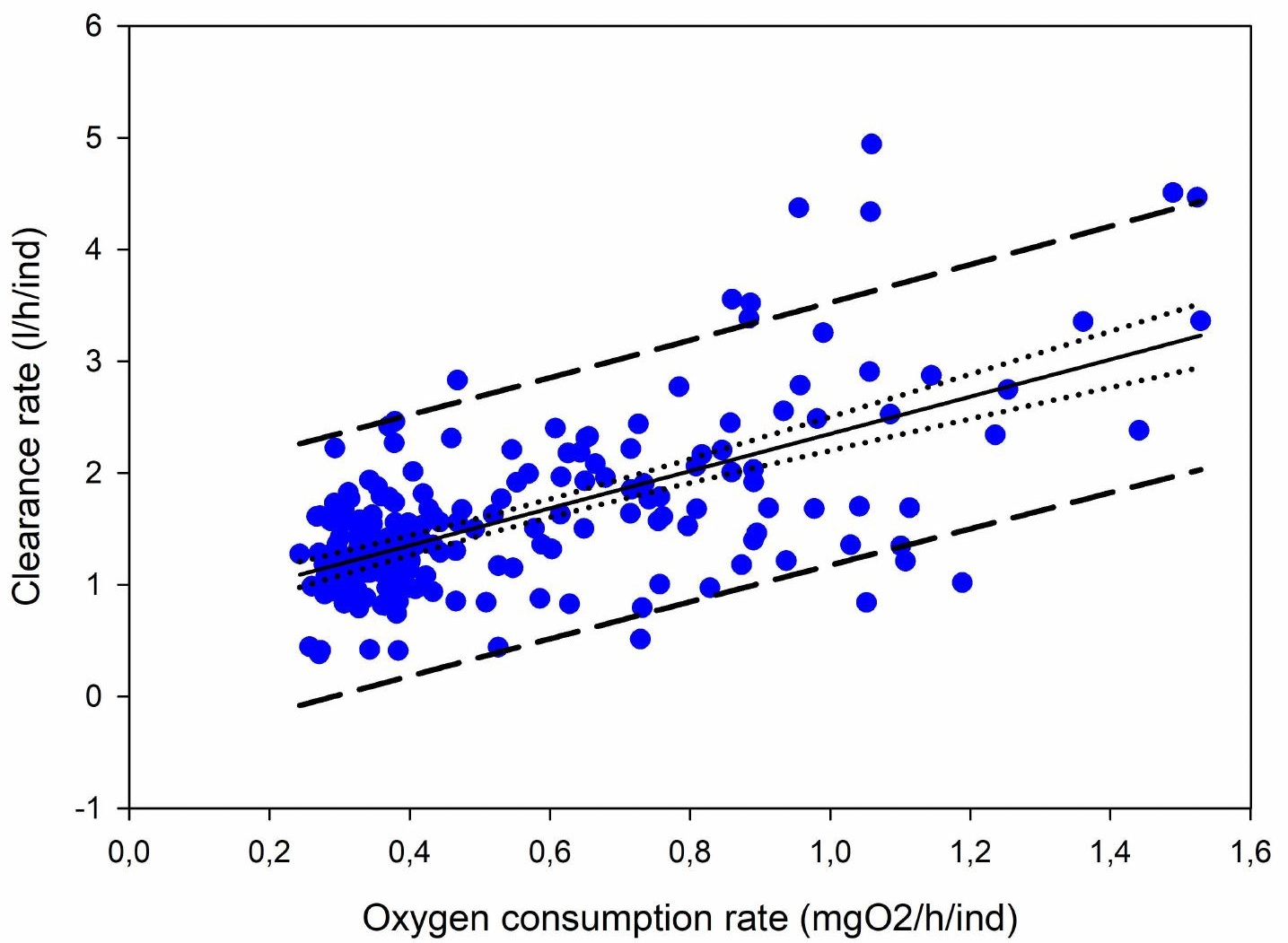

